\title{
One-Step One Chemical Synthesis Process of Graphene from Rice Husk for Energy Storage Applications
}

\author{
Pushpendra Singh1, Jitendra Bahadur1, Kaushik Pal1,2* \\ ${ }^{1}$ Centre of Nanotechnology, Indian Institute of Technology, Roorkee, India \\ ${ }^{2}$ Department of Mechanical and Industrial Engineering, Indian Institute of Technology, Roorkee, India \\ Email: *pl_kshk@yahoo.co.in
}

How to cite this paper: Singh, P., Bahadur, J. and Pal, K. (2017) One-Step One Chemical Synthesis Process of Graphene from Rice Husk for Energy Storage Applications. Graphene, 6, 61-71.

https://doi.org/10.4236/graphene.2017.63005

Received: April 10, 2017

Accepted: May 5, 2017

Published: May 8, 2017

Copyright @ 2017 by authors and Scientific Research Publishing Inc. This work is licensed under the Creative Commons Attribution International License (CC BY 4.0).

http://creativecommons.org/licenses/by/4.0/

\section{(c) (i) Open Access}

\begin{abstract}
Few layer graphene was synthesized using rice husk ash (RHA) and potassium hydroxide $(\mathrm{KOH})$. This methodology demonstrates the utility of RHA as carbon source for graphene synthesis and as a protective barrier against oxidation of parent rice husk and $\mathrm{KOH}$ mixture. Oxidation may occur during synthesis process due to high temperature annealing of RHA and $\mathrm{KOH}$ mixture. Electrochemical characterization showed decent capacitance value $86 \mathrm{~F} \cdot \mathrm{g}^{-1}$ at $500 \mathrm{mV} \cdot \mathrm{s}^{-1}$. XRD and Raman spectroscopy analysis confirmed the presence of graphitic structure. Transmission electron microscopy visually confirmed presence of few layer graphene. Novelty of this synthesis technique can be described as one-pot, one chemical synthesis technique. Use of natural precursor makes this technique highly cost effective for large scale production.
\end{abstract}

\section{Keywords}

Rice Husk, Graphene, Silicon Dioxide, Cyclic Voltammetry

\section{Introduction}

Graphene is a 2D carbon allotrope with honeycomb lattice structure. Individual carbon atoms are bonded by $\mathrm{sp}^{2}$ hybridization [1]. Graphene has outstanding properties like: excellent electrical and thermal conductivity, flexibility, optical transparency, high specific surface area and much more. These properties make it suitable for various applications, like energy storage and harvesting application (super capacitors, battery, solar cell and so on) [2]-[7], fabrication of transistors [8] [9], biomedical application [10] [11], designing mechanically robust materials [12] [13] [14] [15] etc.

Synthesis of single layer of graphite has been reported as early as in 1975 by B. 
Lang [16]. After some scattered attempts by various scientist, finally Novoselov et al. have gained the credit for discovery of graphene in 2004 [17]. They introduced a reproducible technique of graphene synthesis by mechanical exfoliation but this technique is not suitable for large scale production. There are some other well established methods also available for synthesis of graphene such as chemical vapour deposition, chemical reduction of graphene oxide and epitaxial growth on silicon carbide.

Currently, many researchers are trying to develop green synthesis methods for graphene production [18] [19] [20]. The purpose of green synthesis process is to use less toxic chemicals and natural precursor. Muramatsu et al. have reported synthesis of graphene from rice husk using $\mathrm{KOH}$ and carbon black [20].

In this research work, we have successfully replaced carbon black by Rice husk itself, in this way, this approach become even more cost effective synthesis methodology. In our synthesis process we have used RHA as carbon source for graphene synthesis and $\mathrm{KOH}$ as activation agent. The obtained results have revealed successful synthesis of few layer graphene. Cyclic voltammetry has been performed to evaluate electrochemical performance for energy storage application.

\section{Materials and Methods}

The synthesis process is shown in Figure 1, in typical synthesis process, analytical grade reagent $\mathrm{KOH}$ and rice husk were purchased from local market. In typical synthesis process, rice husk collected from local rice mill, was washed several times to remove silica and other contamination as much as possible. After washing, the RHA was prepared by the combustion of rice husk into air. Furthermore, $3 \mathrm{gm}$ of rice husk ash was mixed with $15 \mathrm{gm}$ of $\mathrm{KOH}$ and followed by grinding process for $15 \mathrm{~min}$. The mixture of rice husk and $\mathrm{KOH}$ was compacted into porcelain crucible. This crucible was covered with ceramic wool and fixed into a larger graphite crucible. The top of the graphite crucible was covered

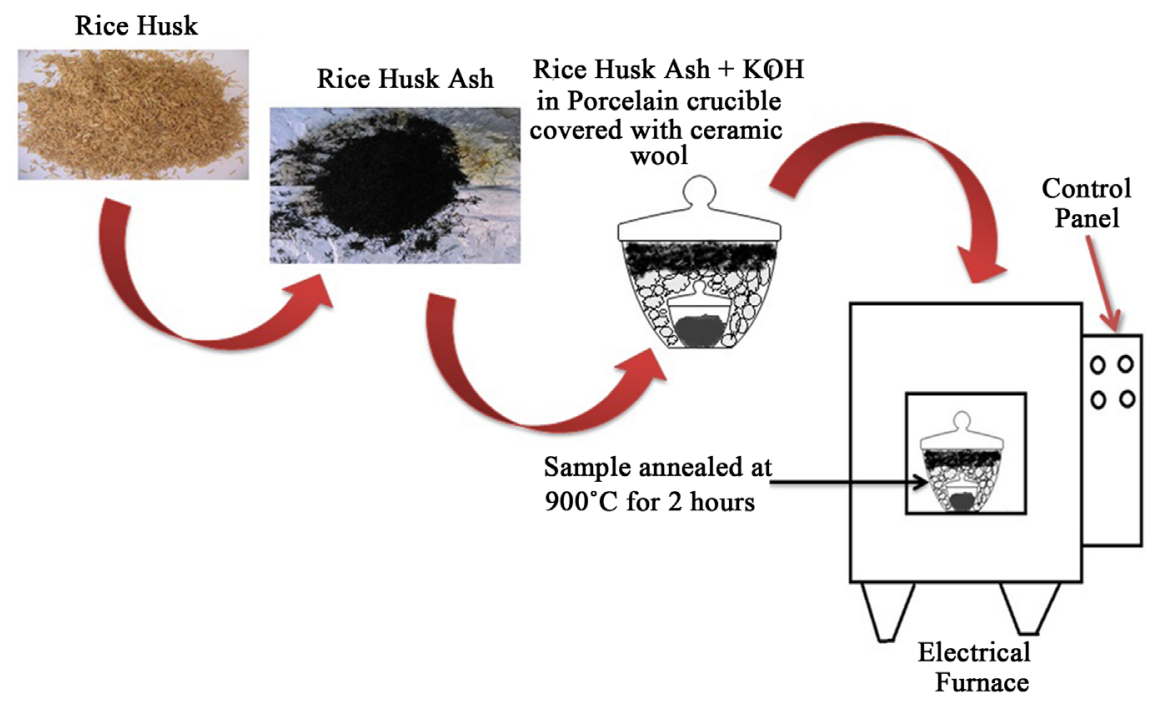

Figure 1. Experimental set-up for synthesis of RHA derived graphene. 
with sufficient amount of sacrificial RHA to provide a barrier against oxidation of the sample inside porcelain crucible. This sample was annealed at $900^{\circ} \mathrm{C}$ for 2 hours in muffle furnace. After this activation treatment, sample was washed several times with distilled water to remove excess $\mathrm{KOH}$ and dried at $100^{\circ} \mathrm{C}$ for 24 hours.

Synthesized material was characterized by Field emission scanning electron microscopy (FESEM) Zeiss-Ultra Plus, Gemini Co. Transmission Electron Microscopy (TEM) images were obtained using TECNAI G2 20 S-TWIN (FEI Netherlands), X-ray diffraction (XRD) study was done by Bruker AXS Diffractometer D8, Thermal analysis of the synthesized sample was done using Thermogravimetric analysis (TGA) SII 6300 Exstar Instrument from 0 to $820^{\circ} \mathrm{C}$ at constant scanning rate of $10^{\circ} \mathrm{C} / \mathrm{min}$; Fourier transform infrared spectroscopy (FTIR) by Perkin Elmer, Raman spectroscopy by InviaRenishaw Raman spectrophotometer with Excitation Wavelength of $514 \mathrm{~nm}$ Argon ion laser were done. Cyclic voltammetry has been used for electrochemical analysis of the specimen using Basi EC epsilon-EClipse.

\section{Results and Discussion}

The FESEM images of successfully synthesized Graphene by activation treatment of RHA using $\mathrm{KOH}$ are shown in Figure 2. From this morphological analysis, flakes of graphene sheets with silica nanoparticles can be observed clearly. Herein, the dual function of $\mathrm{KOH}$ is; removal of amorphous carbon and separation of individual graphene sheet by intercalation of potassium atoms.

TEM images of RHA derived graphene by $\mathrm{KOH}$ activation are shown in above Figure 3. The micro graphical images have confirmed the synthesis of few layer graphene. From these images, we can observe the few layer graphene and agglomeration of silica particles. In the inset, selected area electron diffraction pattern (SAED) has shown, the individual spots have merged into the rings. This shows the characteristic of polycrystalline sample [21] and suggests the stacking of graphene sheets and aggregation of silica particles with random arrangement.

FTIR spectrum of rice husk derived graphene-silica composite is shown in Figure 4. From FTIR spectra, the adsorption band at $1040 \mathrm{~cm}^{-1}$ and $660 \mathrm{~cm}^{-1}$ which reflect asymmetric and symmetric stretches of $\mathrm{Si}-\mathrm{O}-\mathrm{Si}$, respectively [22]. Moreover, the absorption band at $1420 \mathrm{~cm}^{-1}$ has been observed due to the Si-O-C=O bonding [23] and the peak at $1600 \mathrm{~cm}^{-1}$ in the spectrum confirms the presence of aromatic $-\mathrm{C}=\mathrm{C}$ - bond [24]. The infrared band at $3000-3500 \mathrm{~cm}^{-1}$ appears due to the asymmetric stretching and bending vibration of surface hydroxyls and adsorbed water [25].

XRD pattern of prepared graphene by the activating of RHA using $\mathrm{KOH}$ at $900^{\circ} \mathrm{C}$ is shown in Figure 5. From XRD analysis, the diffraction peaks around $20.96^{\circ}, 45.66^{\circ}$ have been assigned with lattice plane (111) of cristobalite silica (JCPDS card No.: 89-3435) and (100) corresponds to graphitic structure of carbon, the weak intense peaks (100) of graphene specifies the non-appearance of a repeatedly stacked graphitic structure [20]. 


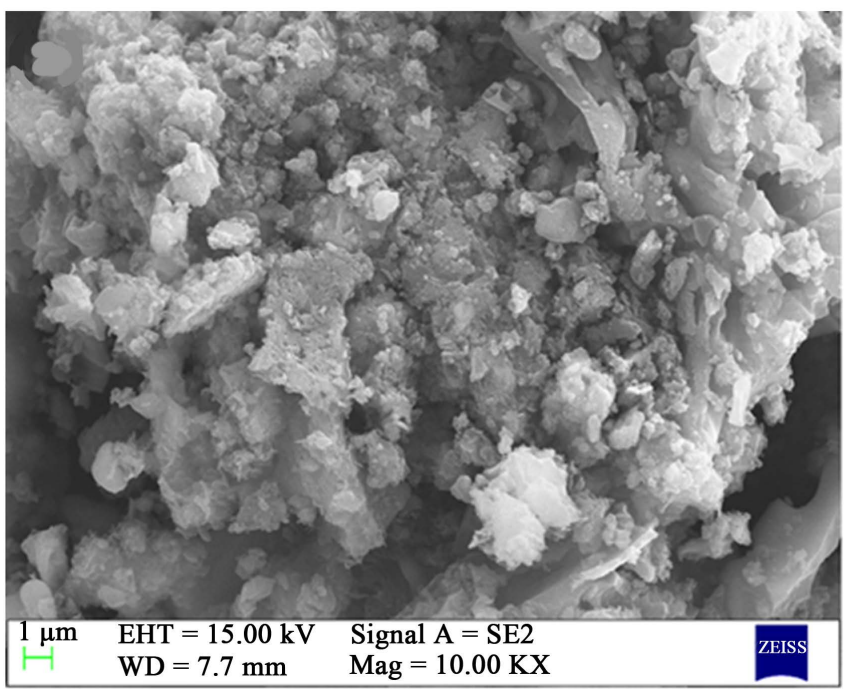

(a)

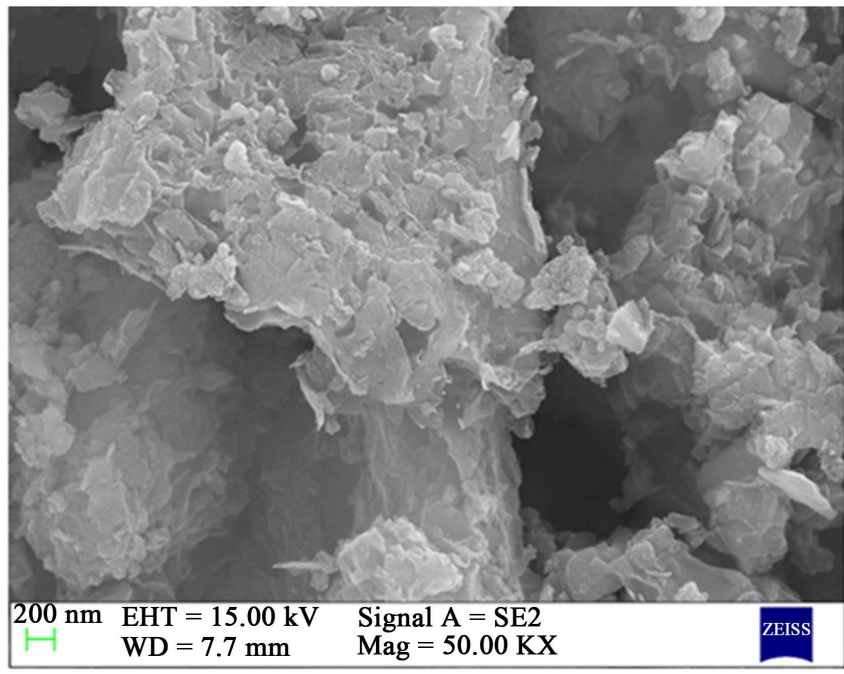

(b)

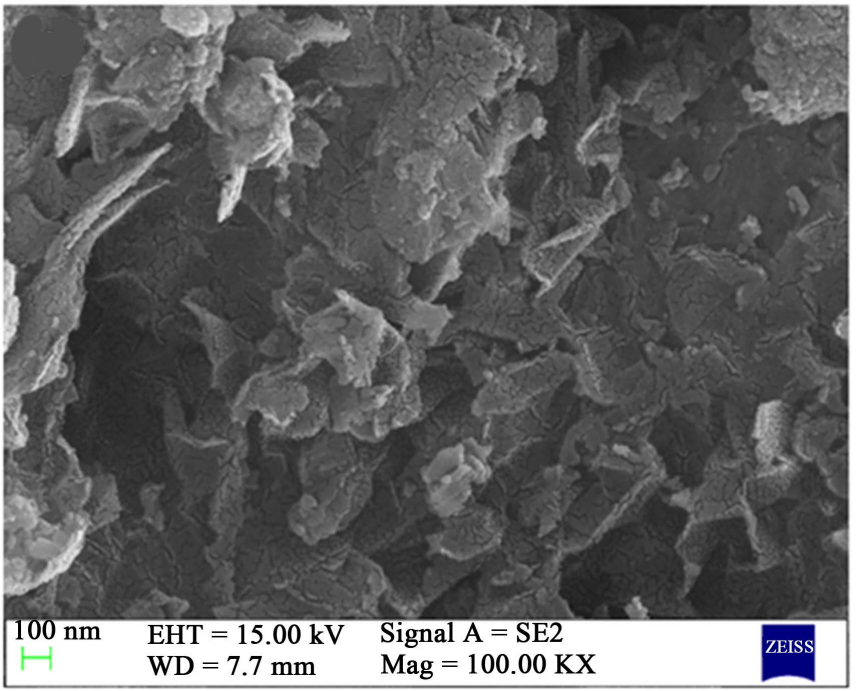

(c)

Figure 2. FESEM images of as prepared RHA derived graphene. 


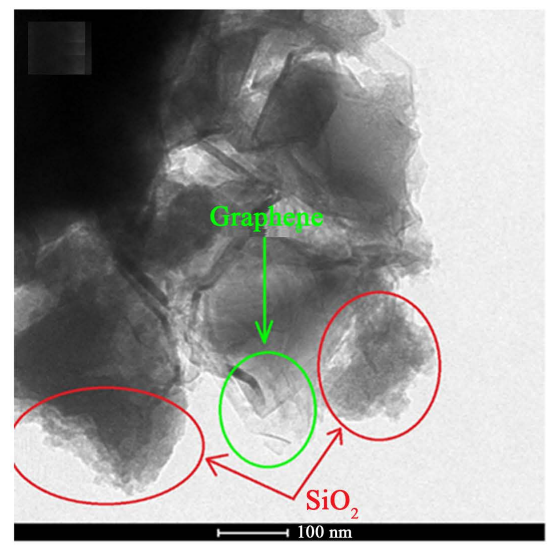

(a)

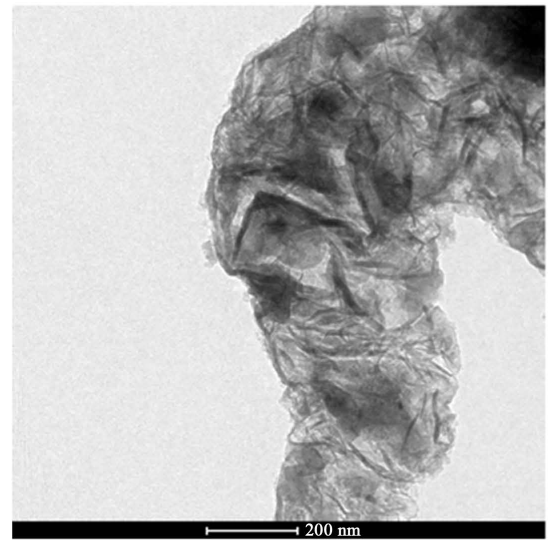

(c)

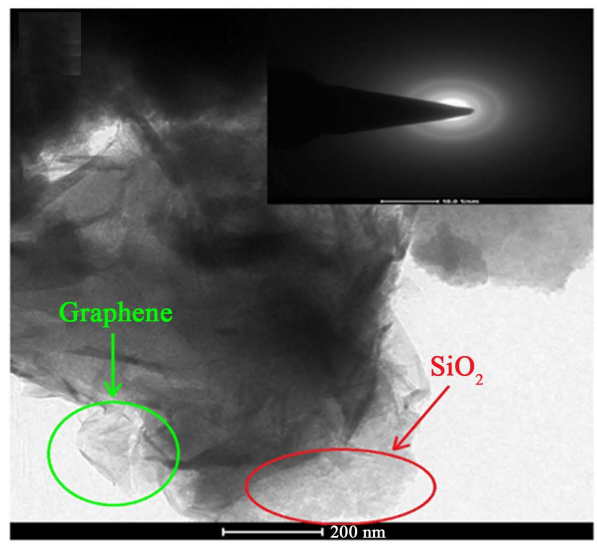

(b)

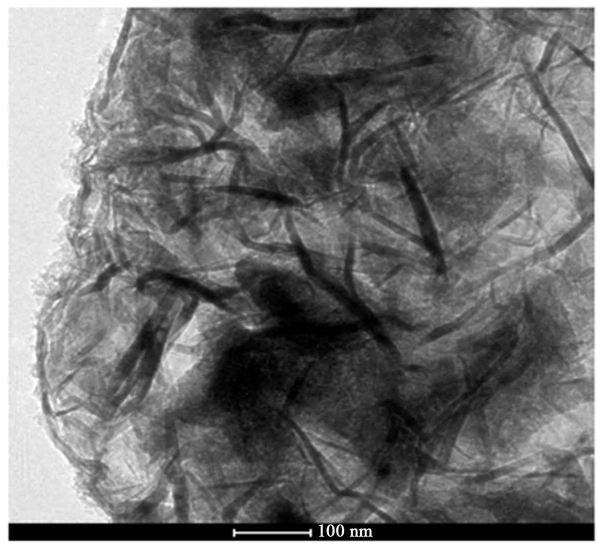

(d)

Figure 3. TEM images of RHA derived graphene at different magnification.

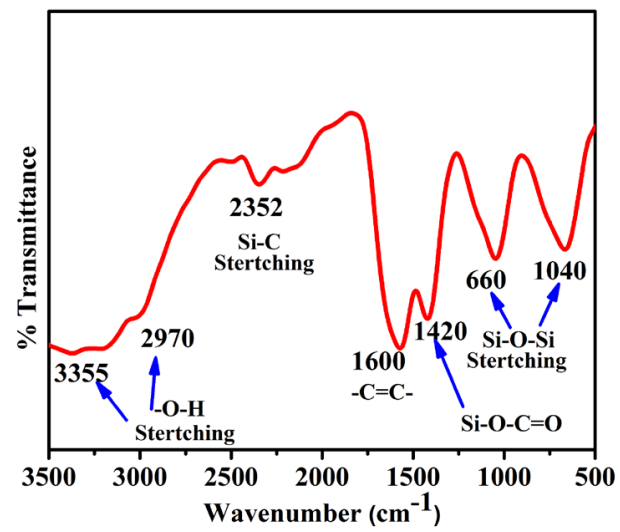

Figure 4. FTIR spectrum of RHA derived graphene.

Raman spectrum of synthesized graphene has shown in Figure 6. From spectra, we can observe most prominent intense peak at 1350, 1582 and $2699 \mathrm{~cm}^{-1}$ which reflects the D, G and G' band, respectively. G band has shown graphitic structure of synthesized sample, sensitive to strain effects and layers of graphene. Also, the position of frequencies shift in Raman spectra has directly related to number of graphene layers present in the sample. The presence of D band has confirmed the defects which may be originated from grain boundaries, doping 


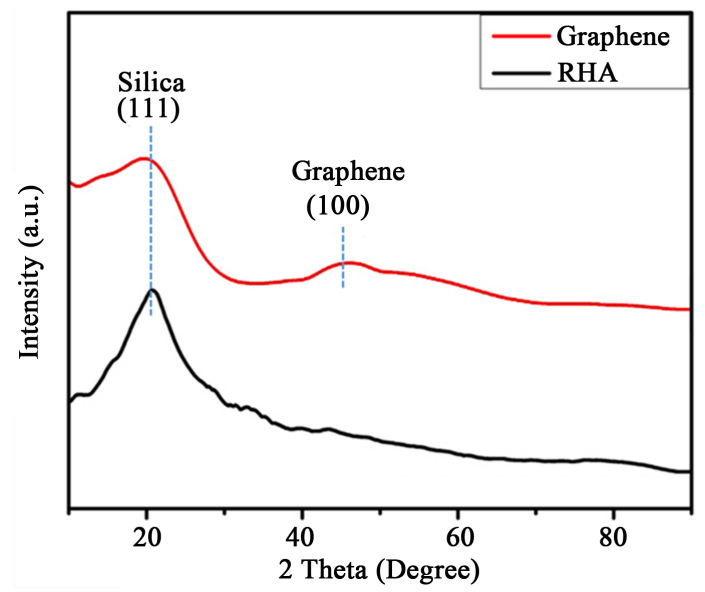

Figure 5. XRD pattern of RHA and RHA derived graphene.

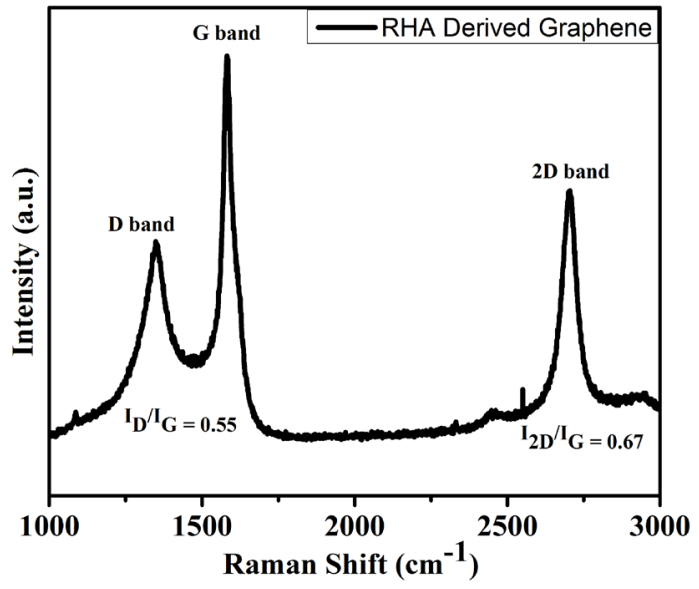

Figure 6. Raman spectrum of RHA derived graphene.

etc. in the sample. The $\mathrm{G}^{\prime}$ band also known as $2 \mathrm{D}$ band induced due to phonon scattering process. In our case, the intensity of $\mathrm{G}$ band is observed much higher greater than $\mathrm{D}$ band. The $\mathrm{I}_{\mathrm{D}} / \mathrm{I}_{\mathrm{G}}$ ratio from Raman spectra has been found 0.55 . This result attributes to more graphitic structure present in RHA derived graphene. Das et al. [25] proved that, the $\mathrm{I}_{\mathrm{D} /} \mathrm{I}_{2 \mathrm{G}}$ intensity ratio was found $\sim 0.24$ for single layer graphene. Moreover, Das et al. also suggest that, $\mathrm{I}_{\mathrm{D} /} \mathrm{I}_{2 \mathrm{G}}$ intensity ratio linearly increases up to 6-8 layers. In present analysis, the obtained $\mathrm{I}_{\mathrm{D} /} \mathrm{I}_{2 \mathrm{G}}$ intensity ratio is found to be $\sim 0.67$, which indicates the synthesized sample contains few layer graphene. This conclusion is in best consent to our TEM images as it can be observed that synthesized graphene is no single layer.

The thermal behaviour of synthesized rice husk derived graphene is probed using thermogravimetric analysis (TGA) as shown in Figure 7. From TGA curve, it was found to $\sim 17.80 \%$ of weight loss up to $400^{\circ} \mathrm{C}$, which is due to evaporation of physically adsorbed water content and may be attached functional group like hydroxyl from the synthesized sample. Thereafter, a weight loss of $\sim 47.60 \%$ observed from $400^{\circ} \mathrm{C}-730^{\circ} \mathrm{C}$, which is attributed to decomposition of carbon in the synthesized simple. Haung et al. [26] have been shown the thermal stability of bare silica after $700^{\circ} \mathrm{C}$. Therefore, from TGA analysis, we can 


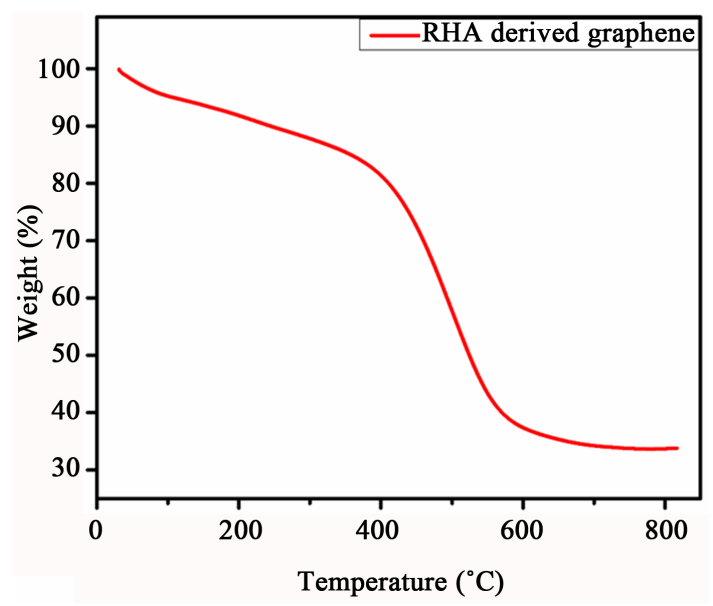

Figure 7. TGA analysis of RHA derived graphene.

conclude that, the Silica $\left(\mathrm{SiO}_{2}\right)$ content is $33.9(100-64.1=34.6) \%$ in the prepared sample.

We finally studied the electrochemical analysis of our sample. The working electrode for electrochemical analysis was prepared using $80 \mathrm{wt} \%$ active material, $10 \mathrm{wt} \%$ graphite powder as a conductive material, and $10 \mathrm{wt} \%$ PVDF as a binder. These materials were mixed using DMF as a solvent to prepare the slurry. The slurry was deposited on stainless steel sheet $(1 \mathrm{~cm} \times 1 \mathrm{~cm})$ and dried in oven at $100^{\circ} \mathrm{C}$ for 12 hours to prepare working electrode. Finally, the electrode was assembled in three electrode configuration with standard $\mathrm{Ag} / \mathrm{AgCl}$ electrode as the reference and platinum wire as a counter electrode. $1 \mathrm{M} \mathrm{Na}_{2} \mathrm{SO}_{4}$ solution was used as the electrolyte. The specific capacitance ( $\left.\mathrm{F} \cdot \mathrm{g}^{-1}\right)$ of prepared sample was calculated from CV curve using the equation (1)

$$
C s p=\frac{i}{M v}
$$

where $i$ is the average current $(\mathrm{A}), v$ is the scan rate $\left(\mathrm{V} \cdot \mathrm{s}^{-1}\right)$ and $\mathrm{M}$ is the mass of working electrode $(\mathrm{g})$ [27]. The specific capacitance of RHA derived graphene was calculated according to the Equation (1) and has been found $86 \mathrm{~F} \cdot \mathrm{g}^{-1}$ at 500 $\mathrm{mV} \cdot \mathrm{s}^{-1}$. Moreover distortion in $\mathrm{CV}$ curve as seen from Figure 8 is suggested due to slow electron transfer process because of silica content in the sample [28]. A Brief comparison of various graphene synthesis method is shown in Table 1.

\section{Conclusion}

We have demonstrated very simple, one-pot, one chemical approach to synthesize graphene from rice husk. Transmission electron microscopy revealed the synthesis of few layer graphene with nanosized silica content. XRD analysis has also confirmed the synthesis of few layers graphene. From Raman spectroscopy it was found that $I_{D} / I_{G}$ predicted less defects in graphene sheets. Capacitance value may not be up to the mark, but this approach can be used to synthesize cheaper graphene. Here we want to mention that, although silica was not desirable in the synthesized graphene but presence of Nano sized silica may be benefi- 


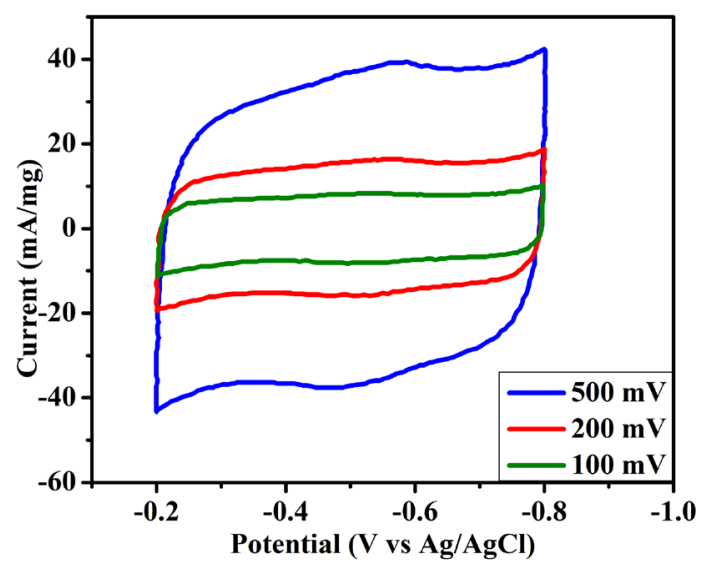

Figure 8. CV curves of RHA derived graphene at 500,200 and $100 \mathrm{mV} / \mathrm{s}^{-1}$ scan rates.

Table 1. The synthesis of graphene with different approaches and their capacitive performance analysis.

\begin{tabular}{|c|c|c|c|c|c|}
\hline S. No. & Authors & Synthesized material & $\begin{array}{l}\text { Specific } \\
\text { capacitance }\end{array}$ & $\begin{array}{l}\text { Scan rate } \\
(\mathrm{mV} / \mathrm{sec})\end{array}$ & Reference \\
\hline 1. & Zhang et al. & $\begin{array}{c}\text { Tetrabutyl ammonium } \\
\text { hydroxide stabilized graphene }\end{array}$ & $192 \mathrm{~F} \cdot \mathrm{g}^{-1}$ & 100 & [29] \\
\hline 2. & Muramatsu et al. & $\begin{array}{l}\text { Rice husk derived graphene } \\
\text { using carbon black as a } \\
\text { protective oxidation layer }\end{array}$ & $80 \mathrm{~F} \cdot \mathrm{g}^{-1}$ & - & 20 \\
\hline 3. & Stoller et al. & Chemically modified graphene & $106 \mathrm{~F} \cdot \mathrm{g}^{-1}$ & 40 & {$[30]$} \\
\hline 4. & Yang et al. & Solvated graphene & $215 \mathrm{~F} \cdot \mathrm{g}^{-1}$ & - & [31] \\
\hline 5. & Singh et al. & $\begin{array}{l}\text { Rice husk derived graphene } \\
\text { using rice husk ash } \\
\text { as a protective oxidation layer }\end{array}$ & $86 \mathrm{~F} \cdot \mathrm{g}^{-1}$ & 500 & $\begin{array}{l}\text { Present } \\
\text { work }\end{array}$ \\
\hline
\end{tabular}

cial for Li-ion battery based energy storage devices. It has been well documented that introduction of silica increases capacity, cyclic stability, and efficiency of electrode [32] [33] [34] [35]. Another added advantage is that, presence of silica can improve thermal stability of the electrode.

\section{Acknowledgements}

This work is supported by research fellowship provided by University Grant Commission (India) followed by Indian Institute of Technology Roorkeefor providing the lab facility.

\section{References}

[1] Novoselov, K.S., Falko, V.I., Colombo, L., Gellert, P.R., Schwab, M.G. and Kim, K. (2012) A Roadmap for Graphene. Nature, 490, 192-200. https://doi.org/10.1038/nature11458

[2] Tan, Y.B. and Lee, J.M. (2013) Graphene for Supercapacitor Applications. Journal of Materials Chemistry A, 1, 14814-14843. https://doi.org/10.1039/c3ta12193c

[3] Liu, C., Yu, Z., Neff, D., Zhamu, A. and Jang, B.Z. (2010) Graphene-Based Super- 
capacitor with an Ultrahigh Energy Density. Nano Letters, 10, 4863-4868. https://doi.org/10.1021/nl102661q

[4] Yu, A., Roes, I., Davies, A. and Chen, Z. (2010) Ultrathin, Transparent, and Flexible Graphene Films for Supercapacitor Application. Applied Physics Letters, 96, Article ID: 253105. https://doi.org/10.1063/1.3455879

[5] Mishra, A.K. and Ramaprabhu, S. (2011) Functionalized Graphene-Based Nano Composites for Supercapacitor Application. Journal of physical Chemistry C, 115, 14006-14013. https://doi.org/10.1021/jp201673e

[6] Lin, T., Huang, F., Lianga, J. and Wang, Y. (2011) A Facile Preparation Route for Boron-Doped Graphene, and Its CdTe Solar Cell Application. Energy \& Environmental Science, 4, 862-865. https://doi.org/10.1039/C0EE00512F

[7] Wang, X., Zhi, L. and Mullen, K. (2007) Transparent Conductive GrapheneElec Trodes for Dye-Sensitized Solar Cells. Nano Letters, 8, 323-327. https://doi.org/10.1021/nl072838r

[8] Xia, F., Mueller, T., Golizadeh-Mojarad, R., Freitag, M., Lin, Y.M., Tsang, J., Perebeinos, V. and Avouris, P. (2009) Photocurrent Imaging and Efficient Photon Detection in a Graphene Transistor. Nano Letters, 9, 1039-1044.

https://doi.org/10.1021/nl8033812

[9] Stampfer, C., Schurtenberger, E., Molitor, F., Guttinger, J., Ihn, T. and Ensslin, K. (2008) Tunable Graphene Single Electron Transistor. Nano Letters, 8, 2378-2383. https://doi.org/10.1021/nl801225h

[10] Zhang, Y., Nayak, T.R., Hongb, H. and Cai, W. (2012) Graphene: A Versatile Nanoplatform for Biomedical Applications. Nanoscale, 4, 3833-3842. https://doi.org/10.1039/c2nr31040f

[11] Chung, C., Kim, Y.K., Shin, D., Ryoo, S.R., Hong, B.H. and Min, D.H. (2013) Biomedical Applications of Graphene and Graphene Oxide. Account of Chemical Research, 46, 2211-2224. https://doi.org/10.1021/ar300159f

[12] Rafiee, M.A., Rafiee, J., Wang, Z., Song, H., Yu, Z.Z. and Koratkar, N. (2009) Enhanced Mechanical Properties of Nanocomposites at Low Graphene Content. ACS Nano, 3, 3884-3890. https://doi.org/10.1021/nn9010472

[13] Zhao, X., Zhang, Q. and Chen, D. (2010) Enhanced Mechanical Properties of Graphene-Based Poly (Vinyl Alcohol) Composites. Macromolecules, 43, 2357-2363. https://doi.org/10.1021/ma902862u

[14] Frank, I.W., Tanenbaum, D.M., van der Zande, A.M. and McEuen, P.L. (2007) Mechanical Properties of Suspended Graphene Sheets. Journal of Vacuum Science \& Technology B, 25, 2558-2561. https://doi.org/10.1116/1.2789446

[15] Min, K. and Aluru, N.R. (2011) Mechanical Properties of Graphene under Shear Deformation. Applied Physics Letters, 98, 13111-13113. https://doi.org/10.1063/1.3534787

[16] Lang, B. (1975) A Leed Study of the Deposition of Carbon on Platinum Crystal Surfaces. Surface Science, 53, 317-329. https://doi.org/10.1016/0039-6028(75)90132-6

[17] Novoselov, K.S., Geim, A.K., Morozov, S.V., Jiang, D., Zhang, Y., Du bonos, S.V., Grigorieva, I.V. and Firsov, A.A. (2004) Electric Field Effect in Atomically Thin Carbon Films. Science, 306, 666-669. https://doi.org/10.1126/science.1102896

[18] Zhu, C., Guo, S., Fang, Y. and Dong, S. (2010) Reducing Sugar: New Functional Molecules for the Green Synthesis of Graphene Nanosheets. ACS Nano, 4, 24292437. https://doi.org/10.1021/nn1002387

[19] Ruiz-Hitzky, E., Darder, M., Fernandes, F.M., Zatile, E., Palomares, F.J. and Aranda, 
P. (2011) Supported Graphene from Natural Resources: Easy Preparation and Applications. Advanced Materials, 23, 5250-5255.

https://doi.org/10.1002/adma.201101988

[20] Muramatsu, H., Kim, Y.A., Yang, K.S., Cruz-Silva, R., Toda, I., Yamada, T., Terrones, M., Endo, M., Hayashi, T. and Saitoh, H. (2014) Rice Husk-Derived Graphene with Nano-Sized Domains and Clean Edges. Small, 10, 2766-2770.

https://doi.org/10.1002/smll.201400017

[21] Barata, J.F.B., Daniel-da-Silva, A.L., Neves, M., Graça, P.M.S., Cavaleiro, J.A.S. and Trindade, T. (2013) Corrole-Silica Hybrid Particles: Synthesis and Effects on Singlet Oxygen Generation. RSC Advances, 3, 274-280.

https://doi.org/10.1039/C2RA22133K

[22] Dalagan, J.Q. and Enriquez, E.P. (2014) One-Step Synthesis of MesoporoussilicaGraphene Composites by Simultaneous Hydrothermal Coupling and Reduction of Grapheme Oxide. Bulletin of Materials Science, 37, 589-595.

https://doi.org/10.1007/s12034-014-0661-6

[23] Yang, T., Liu, L.H., Liu, J.W., Chen, M.L. and Wang, J.H. (2012) Cyanobacte Riummetallothionein Decorated Graphene Oxide Nanosheets for Highly Selective Adsorption of Ultra-Trace Cadmium. Journal of Materials Chemistry, 22, 2190921916. https://doi.org/10.1039/c2jm34712a

[24] Panwar, V., Chattree, A. and Pal, K. (2015) A New Facile Route for Synthesizing of Graphene Oxide Using Mixture of Sulfuric-Nitric-Phosphoric Acids As Intercalating Agent. Physica E, 73, 235-241. https://doi.org/10.1039/c2jm34712a

[25] Das, A., Chakraborty, B. and Sood, A.K. (2008) Raman Spectroscopy of Graphene on Different Substrates and Influence of Defects. Bulletin of Materials Science, 31, 579-584. https://doi.org/10.1007/s12034-008-0090-5

[26] Huang, D., Yang, Z., Li, X., Zhang, L., Hu, J., Su, Y., Hu, N., Yin, G., He, D. and Zhang, Y. (2017) Three-Dimensional Conductive Networks Based on Stacked $\mathrm{SiO}_{2} @ G r a p h e n e$ Frameworks for Enhanced Gas Sensing. Nanoscale, 9, 109-118. https://doi.org/10.1039/C6NR06465E

[27] Lu, T., Pan, L., Li, H., Nie, C., Zhu, M. and Sun, Z. (2011) Reduced Grapheneoxide Carbon Nanotubes Composite Films by Electrophoretic Deposition Method for Supercapacitors. Journal of Electroanalytical Chemistry, 661, 270-273. https://doi.org/10.1016/j.jelechem.2011.07.042

[28] Bettini, L.G., Divitini, G., Ducati, C., Milani, P. and Piseri, P. (2014) Nickel Nanoparticles Effect on the Electrochemical Energy Storage Properties of Carbon Nanocompositefilms. Nanotechnology, 25, 435401. https://doi.org/10.1088/0957-4484/25/43/435401

[29] Zhang, K., Mao, L., Zhang, L.L., Chan, H.S.O., Zhao, X.S. and Wu, J. (2011) Surfactant-Intercalated, Chemically Reduced Graphene Oxide for High Performance Supercapacitor Electrodes. Journal of Materials Chemistry, 21, 7302-7307. https://doi.org/10.1039/cljm00007a

[30] Stoller, M.D., Park, S., Zhu, Y., An, J. and Ruoff, R.S. (2008) Graphene-Based Ultracapacitors. Nano Letters, 8, 3498-3502. https://doi.org/10.1021/nl802558y

[31] Yang, X., Zhu, J., Qiu, L. and Li, D. (2011) Bioinspired Effective Prevention of Restacking in Multilayeredgraphene Films: Towards the Next Generation of HighPerformance Supercapacitors. Advanced Materials, 3, 2833-2838. https://doi.org/10.1002/adma.201100261

[32] Cui, L.F., Hu, L., Choi, J.W. and Cui, Y. (2010) Light-Weight Free-Standing Carbon Nanotube-Silicon Films for Anodes of Lithium Ion Batteries. ACS Nano, 4, 36713678. https://doi.org/10.1021/nn100619m 
[33] Wanga, J., Zhaoa, H., Hea, J., Wanga, C. and Wang, J. (2011) Nano-Sized $\mathrm{SiO}_{\mathrm{x}} / \mathrm{C}$ Composite Anode for Lithium Ion Batteries. Journal of Power Sources, 196, 48114815. https://doi.org/10.1016/j.jpowsour.2011.01.053

[34] Guerfi, A., Charest, P., Dontigny, M., Trottier, J., Lagacé, M., Hovington, P., Vijh, A. and Zaghib, K. (2011) $\mathrm{SiO}_{\mathrm{x}}$-Graphite As Negative for High Energy Li-ion Batteries. Journal of Power Sources, 196, 5667-5673. https://doi.org/10.1016/j.jpowsour.2011.02.018

[35] Yang, J., Takeda, Y., Imanishi, N., Capiglia, C., Xie, J.Y. and Yamamoto, O. (2002) $\mathrm{SiO}_{\mathrm{x}}$-Based Anodes for Secondary Lithium Batteries. Solid State Ionics, 152, 125129. https://doi.org/10.1016/S0167-2738(02)00362-4

\section{Scientific Research Publishing}

Submit or recommend next manuscript to SCIRP and we will provide best service for you:

Accepting pre-submission inquiries through Email, Facebook, LinkedIn, Twitter, etc. A wide selection of journals (inclusive of 9 subjects, more than 200 journals)

Providing 24-hour high-quality service

User-friendly online submission system

Fair and swift peer-review system

Efficient typesetting and proofreading procedure

Display of the result of downloads and visits, as well as the number of cited articles Maximum dissemination of your research work

Submit your manuscript at: http://papersubmission.scirp.org/

Or contact graphene@scirp.org 